\title{
Assessment effects of post-harvest softening on the quality of safou (Dacryodes edulis) produced in Agboville (South-East, Côte d'Ivoire)
}

\author{
Djédjé Blétro Patrick Gérard, Ekissi Elvis Serge Gbocho *, Kadji Beugré Romuald Léonce, Koné Fankroma \\ Martial Thierry and Dabonné Soumaila
}

\begin{abstract}
Laboratory of Biocatalysis and Bioprocessing, Department of Food Science and Technology, Nangui Abrogoua University.
\end{abstract}
Publication history: Received on 20 April 2020; revised on 04 May 2020; accepted on 07 May 2020

Article DOI: https://doi.org/10.30574/gscbps.2020.11.2.0109

\begin{abstract}
The objective of this study was to assess the impact of post-harvest softening on parameters (nutritional and antinutritional) of saffron pulp (Dacryodes edulis). Thus, the safou fruits were picked at physiological maturity and stored at room temperature $\left(27 \pm 1.2^{\circ} \mathrm{C}\right)$ for 12 days during which five stages of softening (S0, S1, S2, S3 and S4) were defined. The softening index of $D$. edulis fruits varied from $0.86 \pm 0.06 \mathrm{~mm}$ to $3.53 \pm 0.03 \mathrm{~mm}$ (edulis) and from $0.85 \pm 0.05 \mathrm{~mm}$ to $2.86 \pm 0.04 \mathrm{~mm}$ (parvicarpa). This study reveals that the softening index is significantly different $(\mathrm{p}<0.05)$ from one variety to another. The contents of total polyphenols decrease significantly during the post-harvest softening and vary from $13.54 \pm 0.2 \mathrm{mg} / \mathrm{g}$ to $2.54 \pm 0.13 \mathrm{mg} / \mathrm{g}$ (edulis), then from $13.31 \pm 0.3 \mathrm{mg} / \mathrm{g}$ at $2.41 \pm 0.1 \mathrm{mg} / \mathrm{g}$ (parvicarpa). The flavonoid contents decrease from $0.71 \pm 0.02 \mathrm{mg} / 100 \mathrm{~g}$ to $0.15 \pm 0.02 \mathrm{mg} / \mathrm{g}$ (edulis) and from $0.69 \pm 0.03 \mathrm{mg} / 100 \mathrm{~g}$ to $0.12 \pm 0.02 \mathrm{mg} / 100 \mathrm{~g}$ (parvicarpa). The tannin content decreases significantly during softening but there is no significant difference between two varieties of safou at each softening stage. The inhibitory concentration of safou increases significantly to the threshold of 5\% during post-harvest softening from one variety to another and no significant difference is observed. Correlation test showed that the softening stage is significantly correlated $(p<0.05)$ with the parameters studied. No significant variation in the content of total oxalates of safou is observed from one variety to another while the phytate contents decrease significantly and the values are respectively $1.46 \pm 0.03 \mathrm{mg} / 100 \mathrm{~g}$ at $0.35 \pm 0.02 \mathrm{mg} / 100 \mathrm{~g}$ (edulis) and from $1.43 \pm 0.01 \mathrm{mg} / 100 \mathrm{~g}$ to $0.31 \pm 0.01 \mathrm{mg} / 100 \mathrm{~g}$ (parvicarpa). The post-harvest softening greatly reduced the anti-nutritional contents in the safou pulp and this led to a loss of its nutritional value.
\end{abstract}

Keywords: Dacryodes edulis; Safou; Softening; Antinutritional and nutritional parameters; Post-harvest

\section{Introduction}

In recent years, attention has focused on unconventional crops that may be of interest for local or industrial development (Ricinodendron heudoletii, Irvingia gabonensis, Dacryodes edulis) of populations in Africa [1,2,3]. The safoutier (Dacryodes edulis), produced in many countries of Central Africa and the Gulf of Guinea [4] has a strong economic potential which can contribute to the reduction of poverty of the rural population [5]. The safou is an ellipsoidal drupe, 4-8 cm long and 3-6 cm wide, depending on the variety [6]. Safou pulp, in view of its very interesting nutritional composition, would thus find its place in the food, pharmaceutical and cosmetic industries $[7,3,8]$. Indeed, several studies have shown that the leaves, pulp, and oil of safou pulp are rich in compounds with antioxidant activities $[9,10,11]$.

The richness of safou in antioxidants justifies its traditional use in the treatment of diseases associated with oxidation, such as cancer, diabetes and high blood pressure $[12,13,11]$. Unfortunately, the potential of safou is not fully exploited due to its rapid softening ( 2 to 3 days) post-harvest (Dossou et al., 2018). Indeed, The safou generally matures on the

\footnotetext{
* Corresponding author: Ekissi Elvis Serge Gbocho
} 
tree and no softening process takes place there. Post-harvest, the safous undergo rapid softening after 2 to 3 days at room temperature, which modifies their nutritional qualities [14]. Compounds with antioxidant activity in fruits and vegetables are generally degraded during post-harvest conservation [15].

In Côte d'Ivoire (West Africa), the culture of safou (Dacryodes edulis) has been booming in recent years. In this context, research work is focused on the promotion and vulgarization of safou. This is how [2] characterized the varieties of safou and studied them as ingredients in the enrichment of infant flours. Subsequently, [16] optimized the extraction of total flavonoids and [3] studied the biochemical and phytochemical composition of pulp meal and safou seed. This work aims to determine the impact of post-harvest softening on nutritional and anti-nutritional parameters of safou (Dacryodes edulis) pulp.

\section{Material and methods}

\subsection{Study and sampling equipment}

Two varieties of safou (Dacryodes edulis) with physiological maturity, were harvested in Grand-Morié (Agboville), in the south-east of Côte d'Ivoire for study (Figure 1, Table 1). After harvest, the safou (two hundred fruits of each variety) were immediately transported to the laboratory where they were stored at room temperature $\left(27 \pm 1.2^{\circ} \mathrm{C}\right)$ for 12 days. Five softening stages (S0, S1, S2, S3, S4) have been defined and samples are taken every three days according to the modified method of [17]:

- $\quad$ S0: First day of harvest;

- $\quad$ S1 : Safou fruits taken after 3 days of harvest and storage

- $\quad$ S2 : Safou fruits taken after 6 days of harvest and storage;

- $\quad$ S3 : Safou fruits taken after 9 days of harvest and storage;

- $\quad$ S4 : Safou fruits taken after 12 days of harvest and storage.

- $\quad$ The different varieties of safou ((Dacryodes edulis) have been defined in the table 1 according to [2].
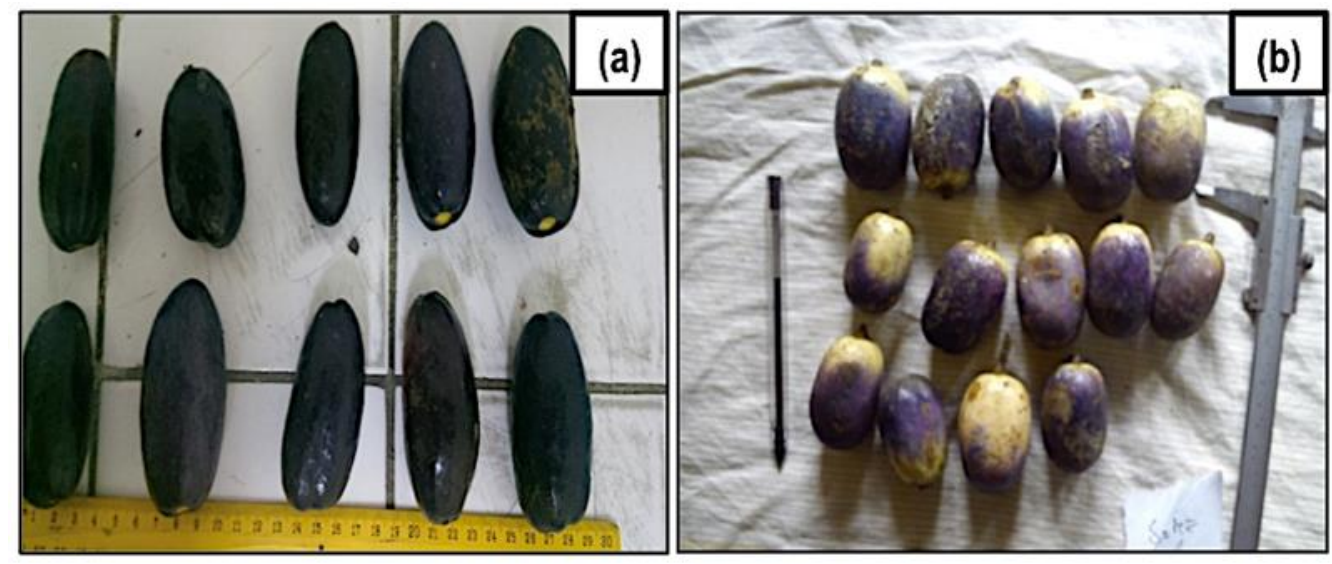

Figure 1 Mature safou fruits: Dacryodes edulis var. edulis (a) and Dacryodes edulis var. parvicarpa (b)

Table 1 Physical characteristics of two safou (Dacryodes edulis) varieties

\begin{tabular}{lllll}
\hline Variety & Weight $(\mathbf{g})$ & Thickness $(\mathbf{m m})$ & Width $(\mathbf{m m})$ & Pulp length $(\mathbf{m m})$ \\
\hline edulis & $49.63 \pm 1.51^{\mathrm{b}}$ & $71.23 \pm 2.54^{\mathrm{b}}$ & $37.65 \pm 1.49^{\mathrm{b}}$ & $3.86 \pm 0.42^{\mathrm{b}}$ \\
parvicarpa & $27.34 \pm 1.42^{\mathrm{a}}$ & $38.37 \pm 1.72^{\mathrm{a}}$ & $33.73 \pm 2.15^{\mathrm{a}}$ & $2.92 \pm 0.63^{\mathrm{a}}$ \\
\hline
\end{tabular}

Average of 50 fruits \pm standard deviation. Means with different letters in the same column indicate significant differences between varieties (p $<0.05$ ). 


\subsection{Analysis methods}

\subsubsection{Penetrometer measurement}

The texture of the fruits expressed in softening index was measured using a penetrometer (K19500, Koehler Instrument Company, INC, United States) equipped with a $47.5 \mathrm{~g}$ piston. The softening index corresponds to the depth of penetration of the piston into the safou pulp. For each softening stage, five safou of each variety were studied. For each safou, twelve measurements were distributed uniformly: four measurements around the peduncle base, four measurements in the safou middle and four measurements at the end opposite peduncle base.

\subsubsection{Biochemical analyzes}

The methanolic extracts were prepared according to [18]. The content of total polyphenols in the safou pulp was determined according to [19]. Tannins content in safou pulp was carried out according to [19]. The flavonoid content was determined by [21] methods. Antioxidant activity of safou pulps was determined by reducing $\mathrm{Fe}_{3}$ to $\mathrm{Fe}_{2}$ according to [22] method. Antioxidant activity by DPPH inhibition was made by [23] Sanchez-Moreno et al. (1998) methods. Phytates content were quantified by [24] method. Oxalates content was carried out according to [25] method using potassium permanganate.

\subsection{Statistical analyzes}

All the analyzes reported in this study were carried out in triplicate. Data were evaluated by analysis of variance (ANOVA) and the Duncan Multiple Range test $(\mathrm{p}<0.05)$. The correlation between the parameters was assessed by Pearson independence test. All statistical analyzes were performed using Statistica 7.1 software (Stat Soft Inc., head office in Tulsa USA).

\section{Results and discussion}

\subsection{Softening index}

The softening index of safou (D. edulis) during postharvest softening are presented in Figure 2. The softening indices of varied from $0.86 \pm 0.06 \mathrm{~mm}$ to $3.53 \pm 0.03 \mathrm{~mm}$ (Var. edulis) and from $0.85 \pm 0.05 \mathrm{~mm}$ to $2.86 \pm 0.04 \mathrm{~mm}$ (Var. parvicarpa). The softening index increases significantly from S0 to S4. In addition, this study reveals that the softening index is significantly different $(\mathrm{p}<0.05)$ from one variety to another.

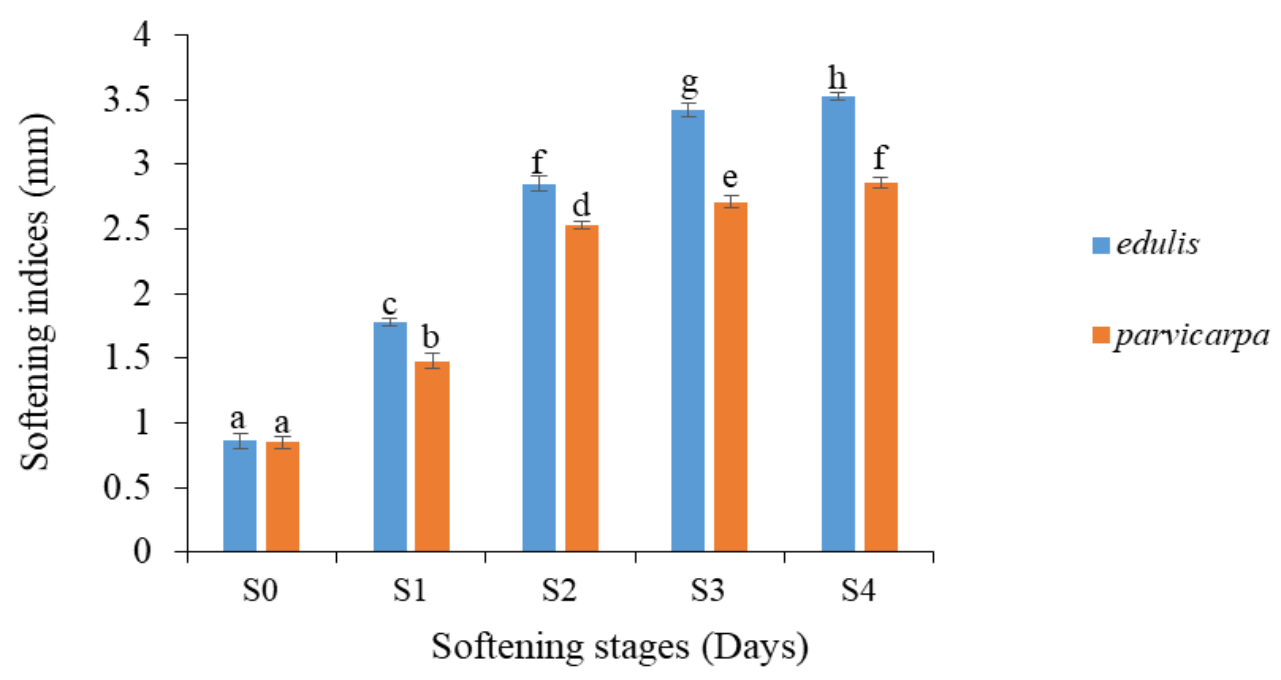

Figure 2 Changes in softening index of safou varieties during softening stages 


\subsection{Phenolic compounds}

\subsubsection{Total polyphenols}

Changes of total polyphenols in safou during post-harvest softening is shown in Figure 3. Total polyphenol contents of the two varieties (safou) are not significantly different. Furthermore, these contents decrease significantly during postharvest softening. The content varied from $13.54 \pm 0.2 \mathrm{mg} / \mathrm{g}$ to $2.54 \pm 0.13 \mathrm{mg} / \mathrm{g}$ (edulis), then from $13.31 \pm 0.3 \mathrm{mg} / \mathrm{g}$ to $2.41 \pm 0.1 \mathrm{mg} / \mathrm{g}$ (parvicarpa).

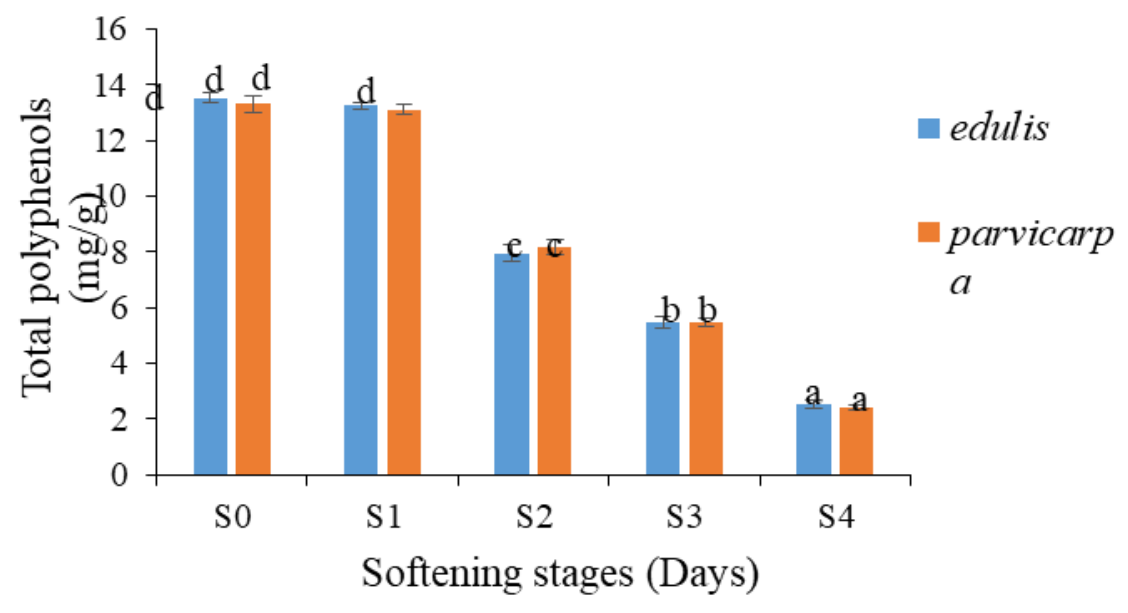

Figure 3 Changes in total Polyphenol Content of safou varieties during softening stages

\subsubsection{Flavonoids}

The flavonoids content in safou during the softening process are shown in figure 4. There is no significant difference between the flavonoids content in two varieties at each softening stages. Flavonoid contents varied from $0.71 \pm 0.02$ $\mathrm{mg} / 100 \mathrm{~g}$ to $0.15 \pm 0.02 \mathrm{mg} / \mathrm{g}$ (edulis) and from $0.69 \pm 0.03 \mathrm{mg} / 100 \mathrm{~g}$ to $0.12 \pm 0.02 \mathrm{mg} / 100 \mathrm{~g}$ (parvicarpa),

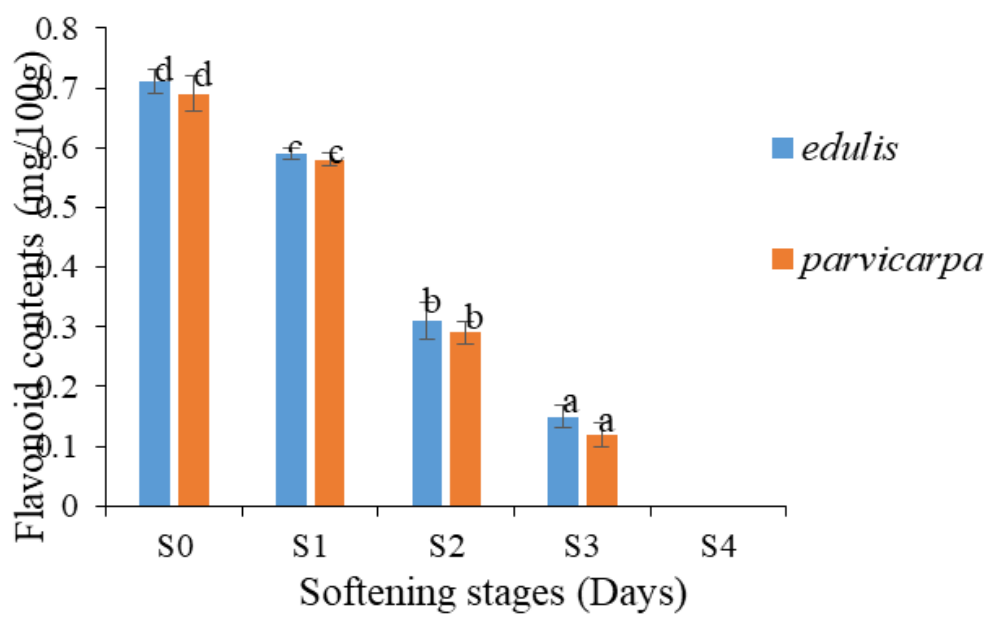

Figure 4 Changes in flavonoid content of safou varieties during softening stages

\subsubsection{Tannins}

Changes of tannin contents of safou varieties during softening stages is presented in figure 5 . There is no significant difference between tannin contents of two varieties at each softening stage. Tannin contents decreased significantly during softening. Contents ranged from $0.66 \pm 0.02 \mathrm{mg} \mathrm{EAT} / \mathrm{g}$ to $0.13 \pm 0.01 \mathrm{mg}$ EAT/g (edulis) and from $0.67 \pm 0.03 \mathrm{mg}$ EAT/g to $0.14 \pm 0.01 \mathrm{mg}$ EAT/g (parvicarpa). 


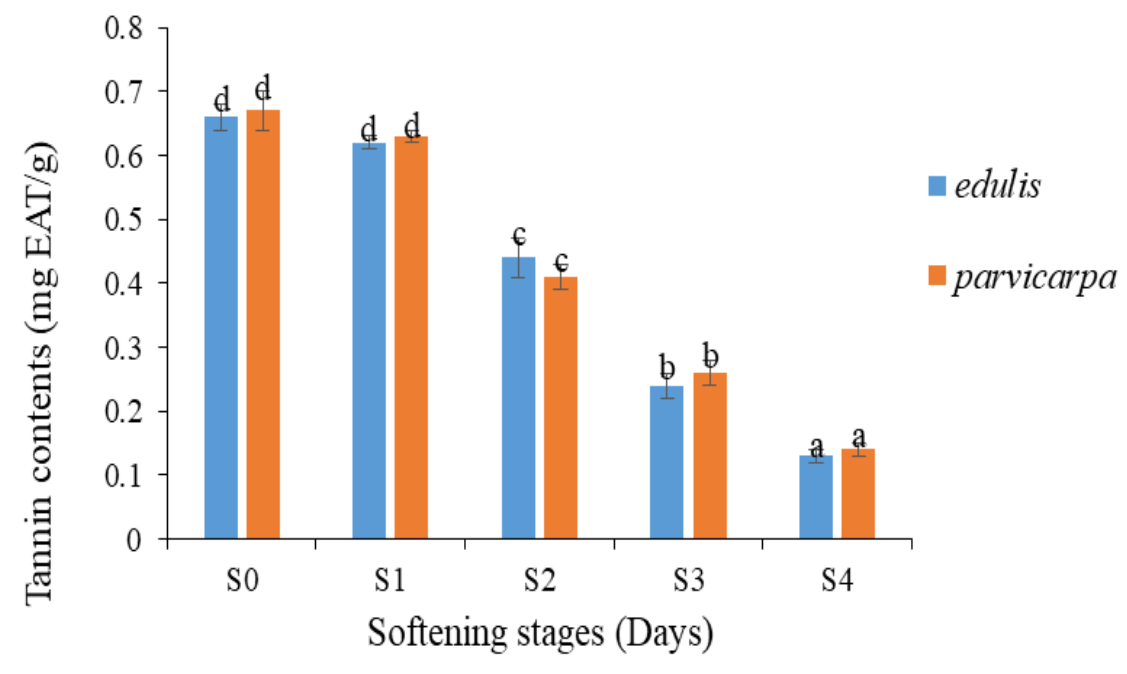

Figure 5 Changes in tannins contents of safou varieties during softening stages

\subsection{Antioxidant activities}

\subsubsection{2,2-Diphenyl-1-picrylehydrazile (DPPH) free radical inhibition capacity}

Changes of the median inhibitory concentration during softening stages of safou varieties is presented in figure 6 . Median inhibitory concentration of safou increased significantly during post-harvest softening from one variety to another. In addition, no significant difference in the median inhibitory concentration was observed. The contents varied from $0.12 \pm 0.02 \mathrm{mg} / \mathrm{mL}$ to $0.32 \pm 0.01 \mathrm{mg} / \mathrm{mL}$ (edulis) and from $0.12 \pm 0.01 \mathrm{mg} / \mathrm{mL}$ to $0.31 \pm 0.01 \mathrm{mg} / \mathrm{mL}$ (parvicarpa).

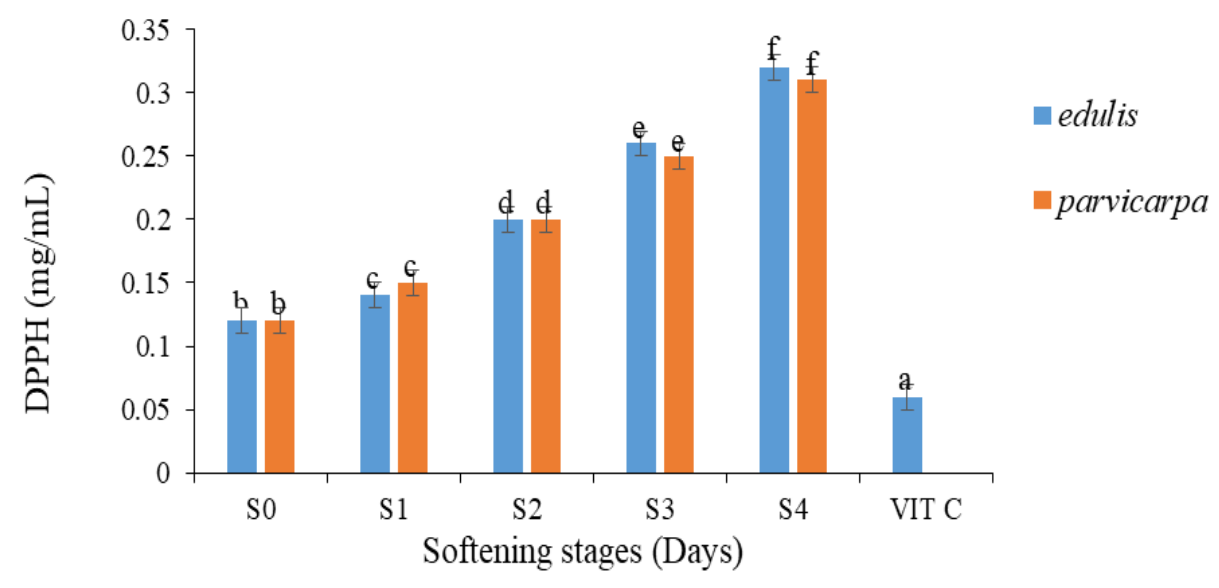

Figure 6 Changes in contents of median inhibitory concentration of safou varieties during softening stages

\subsubsection{Ability to reduce $\mathrm{Fe}_{3}$ to $\mathrm{Fe}_{2}$}

Changes in the reducing power of $\mathrm{Fe}_{3}$ to $\mathrm{Fe}_{2}$ during softening stages of safou varieties is presented in figure 7. The powers to reduce $\mathrm{Fe}_{3}$ to $\mathrm{Fe}_{2}$ in safou significantly decrease at the $5 \%$ threshold from $\mathrm{S} 0$ to $\mathrm{S} 4$. Thus, the reduction power of $\mathrm{Fe}_{3}$ to $\mathrm{Fe}_{2}$ of the safous is respectively $0.61 \pm 0.02$ (S0) to $0.15 \pm 0.01$ (S4) (edulis) and $0.6 \pm 0.01$ (S0) at $0.15 \pm 0.02$ (S4) (parvicarpa). These contents of reduction power of $\mathrm{Fe}_{3}$ to $\mathrm{Fe}_{2}$ of safou varieties are all lower than vitamin $\mathrm{C}$ content $(0.85 \pm 0.03)$ 


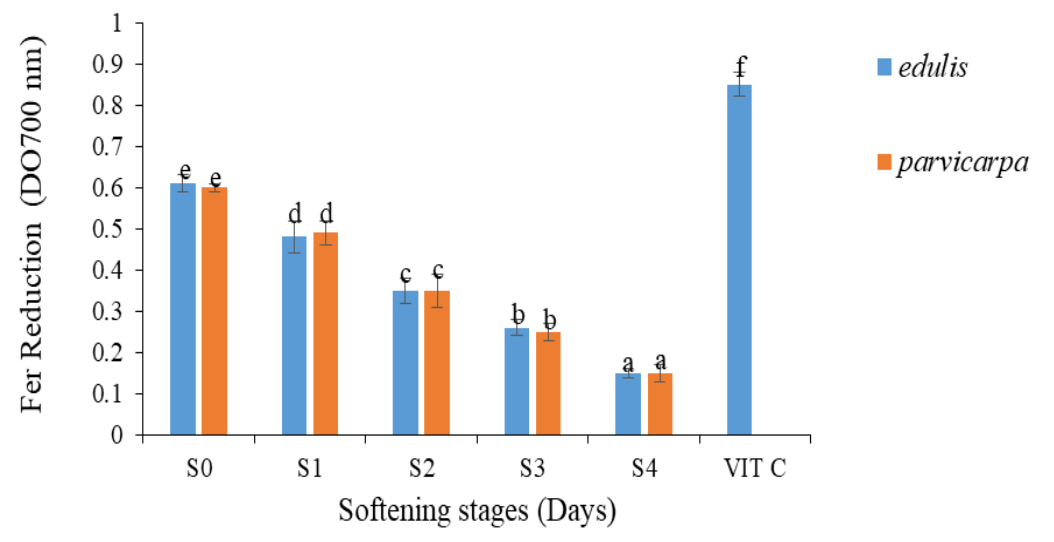

Figure 7 Powers to reduce $\mathrm{Fe}_{3}$ to $\mathrm{Fe}_{2}$ of safou varieties during softening stages.

\subsection{Correlation between softening level, softening index, phenolic compounds and antioxidant activities of safou pulp}

Correlation test shows that the softening stage is significantly correlated $(\mathrm{p}<0.05)$ with the parameters studied (Tables 3 and 4).

Table 3 Linear correlation matrix between softening level, phenolic compounds and antioxidant activities of safou (edulis variety)

\begin{tabular}{|c|c|c|c|c|c|c|c|}
\hline \multicolumn{8}{|c|}{ Edulis variety } \\
\hline & N.R. & P.T. & $\mathbf{T}$ & $\mathbf{F}$ & DPPH & FRAP & I.R. \\
\hline N.R. & 1.00 & & & & & & \\
\hline P.T. & -0.981 & 1.00 & & & & & \\
\hline $\mathrm{T}$ & -0.983 & 0.991 & 1.00 & & & & \\
\hline $\mathrm{F}$ & -0.975 & 0.992 & 0.996 & 1.00 & & & \\
\hline DPPH & 0.988 & -0.991 & -0.995 & -0.997 & 1.00 & & \\
\hline FRAP & -0.997 & 0.977 & 0.972 & 0.963 & -0.977 & 1.00 & \\
\hline I.R. & 0.964 & -0.947 & -0.938 & -0.915 & 0.928 & -0.976 & 1.00 \\
\hline
\end{tabular}

Table 4 Linear correlation matrix between softening level, phenolic compounds and antioxidant activity of safou (parvicarpa variety)

\begin{tabular}{llllllll}
\hline \multicolumn{7}{c}{ Parvicarpa variety } & \multicolumn{7}{c}{} \\
\cline { 2 - 8 } & N.R. & P.T. & T & F & DPPH & FRAP & I.R. \\
\hline N.R. & 1,00 & & & & & & \\
P.T. & -0.9808 & 1.00 & & & & & \\
T & -0.9851 & 0.9985 & 1.00 & & & & \\
F & -0.9728 & 0.9810 & 0.9731 & 1.00 & & & \\
DPPH & 0.9939 & -0.9896 & -0.9895 & -0.9897 & 1.00 & & \\
FRAP & -0.9980 & 0.9824 & 0.9874 & 0.9656 & -0.9887 & 1.00 & \\
I.R. & 0.9459 & -0.9299 & -0.9399 & -0.8801 & 0.9160 & -0.9637 & 1.00 \\
\hline \multicolumn{7}{c}{ N.R. : Softening level; P.T.: Total polyphenol; T: Tannin; F: Flavonoid; I.R.: Softening index * Significant values in bold. }
\end{tabular}




\subsection{Anti-nutritional factors}

\subsubsection{Total oxalates}

Changes of total oxalate content during post-harvest softening of safou varieties are presented in figure 8. No significant variation in total oxalate content of the safou is observed from one variety to another. The contents varied from $4.63 \pm 0.21 \mathrm{mg} / \mathrm{g}$ to $0.84 \pm 0.1 \mathrm{mg} / 100 \mathrm{~g}$ (edulis) and from $4.61 \pm 0.22 \mathrm{mg} / \mathrm{g}$ to $0.79 \pm 0.23 \mathrm{mg} / \mathrm{g}$ (parvicarpa).

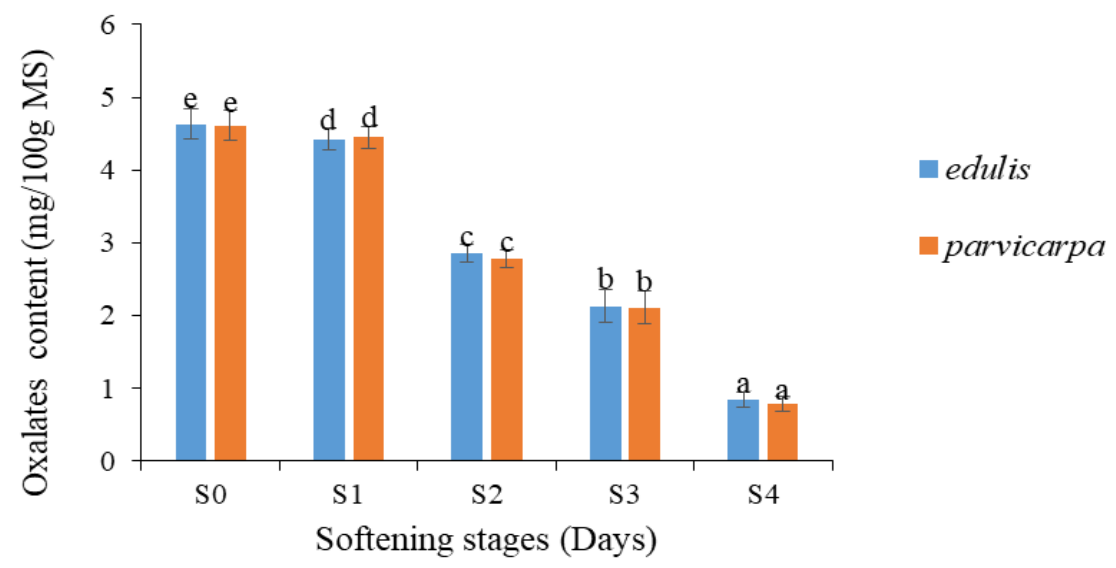

Figure 8 Changes in oxalates contents of safou varieties during softening stages

\subsubsection{Phytates}

Changes of phytates contents during softening stages of safou varieties are presented in figure 9. No significant difference between the phytate contents of safou varieties. The phytate contents decrease significantly during softening stages. The contents are respectively $1.46 \pm 0.03 \mathrm{mg} / 100 \mathrm{~g}$ to $0.35 \pm 0.02 \mathrm{mg} / 100 \mathrm{~g}$ (edulis) and $1.43 \pm 0.01 \mathrm{mg} / 100 \mathrm{~g}$ to $0.31 \pm 0.01 \mathrm{mg} / 100 \mathrm{~g}$ (parvicarpa).

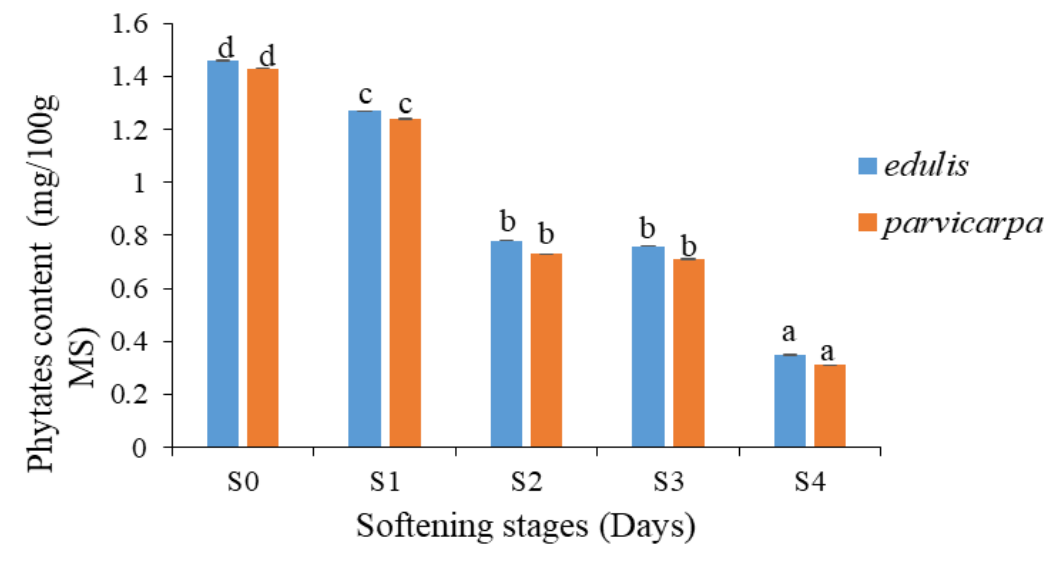

Figure 9 Changes in phytates contents of safou varieties during softening stages

\section{Discussion}

Firmness is an important parameter for determing the quality of fresh fruits and vegetables [26]. The softening index (0.86 mm Var. edulis, $0.85 \mathrm{~mm}$ Var. parvicarpa) taken on the first day of harvest is similar to that of [14] which was 0.85 $\mathrm{mm}$. Third day of harvest, a decrease $(1.78 \mathrm{~mm}$ Var. edulis, $1.48 \mathrm{~mm}$ Var. parvicarpa) in firmness is observed. This is consistent with studies did by $[6,27]$ who reported that post-harvest softening occurs on the third day of storage. This loss of firmness is progressive up to the softening stage (S4). Indeed, according to [14], the softening of safou is due to the progressive and significant degradation of the cell wall carbohydrates during ripening, leading to its disassembly [28]. Thus, softening would be associated with degradation of pectin during the ripening phase [29]. Therefore, the changes undergone by the cell wall polysaccharides during the post-harvest storage would influence the safou texture 
[22]. The change in safou firmness would therefore be associated with the phenomenon of ripening during which the fruits undergo profound biochemical changes. The safou softening index of edulis variety is higher than parvicarpa variety. These results are consistent with those of [30] who reported that the softening speed of safou depend of their size.

Polyphenols play an important role in human health by preventing degenerative pathologies such as cancer, cardiovascular disease or osteoporosis [31]. Polyphenol contents of safou at softening stage S0 (13.54 mg/g (edulis), $13.31 \mathrm{mg} / \mathrm{g}$ (parvicarpa) are close to those $(12.10 \mathrm{mg} / \mathrm{g}$ ) reported by [10] in Nigeria and higher than those obtained from baobab pulp (Andasonia digitata) whose content is $10.84 \mathrm{mg} / \mathrm{g}$ [32] . Polyphenol contents decreased during postharvest softening and this was observed by [15] during the storage of Solanum anguivi berries. Indeed, at the softening stage $S 1$ (third day after harvest), a non-significant decrease $(p>0.05)$ in polyphenol content is observed. This suggests that the polyphenol content of safous studied remains constant from S0 to S1. From stage S1, the polyphenol content decreases significantly up to the softening stage S4. This reduction in polyphenol content could be attributed to phenolic oxidation which characterizes the advanced stages of fruits ripening [33].

Flavonoids are compounds with remarkable antioxidant activity [34]. The flavonoid content of safou at the softening stage S0 is $0.71 \pm 0.02 \mathrm{mg} \mathrm{g}$ (edulis) and $0.69 \pm 0.03 \mathrm{mg} / \mathrm{g}$ (parvicarpa). These contents are close to those reported by [7] $0.67 \pm 0.27 \mathrm{mg} / \mathrm{g}$ for mature safou in Nigeria. The flavonoid content decreased during postharvest softening. This decrease was reported by [9] in a comparative study of fresh and softened safou. In fact, from the softening stage S0, the flavonoid content decreased significantly up to the softening stage S4. This gradual reduction in flavonoid content is said to be due to the action of polyphenol oxidases, peroxidases and catalases which degrade phenolic compounds during enzymatic browning [35]. Indeed, loss of purple coloration due to the presence of flavenols and anthocyanins in favor of the brown color in safou during post-harvest softening would be due to the enzymes responsible for the phenomenon of enzymatic browning [36].

Tannins have beneficial health effects, although they are associated with a decrease in the nutritional value of proteins [37]. The tannin content of safou studied of softening stage S0 is $0.66 \pm 0.02 \mathrm{mgEAT} / \mathrm{g}$ (edulis) and $0.67 \pm 0.03 \mathrm{mg}$ EAT/g (parvicarpa). These contents are similar to those reported by [4] for safou (edulis variety) where the content was $0.68 \pm$ $0.05 \mathrm{mg}$ EAT/g. During post-harvest softening, the tannin content decreased. This was observed by Dan (2014) during the storage of Solanum anguivi berries. It would be attributed to the activation of protein and lipid syntheses during ripening. These biochemical reactions degrade the tannins responsible for astringency [15]. Furthermore, the weakening of cell walls leading to the oxidation of phenolic compounds would also explain this reduction in tannins [38].

The antioxidant activity of safou at softening stage S0 is $0.12 \pm 0.02 \mathrm{mg} \mathrm{ml}$ (edulis) and $0.12 \pm 0.01 \mathrm{mg} \mathrm{ml}$ (parvicarpa) by DPPH method and $0.61 \pm 0.02$ (edulis) and 0.6 \pm 0.01 (parvicarpa) by FRAP method. These values are similar to those reporyted by [4] on safou (edulis variety) which is $0.12 \pm 0.02 \mathrm{mg} / \mathrm{mL}$ (DPPH) and $0.6 \pm 0.03 \mathrm{mg} / \mathrm{mL}$ (FRAP). Antioxidant activity of safou decreased during postharvest softening. This decrease in antioxidant activity was reported by [39] in tomatoes studies (Lycopersicon esculentum). It would be associated with a decrease in phenolic compounds during postharvest softening [40].

\subsection{Effects of post-harvest softening on anti-nutritional factors}

Oxalates form insoluble complexes with calcium, magnesium, iron and zinc, which reduces the absorption of these mineral elements [41]. Total oxalate content of safou is $4.63 \pm 0.21 \mathrm{mg} / \mathrm{g}$ (edulis) and $4.61 \pm 0.22 \mathrm{mg} / \mathrm{g}$ (parvicarpa) at softening stage S0. These contents are comparable to those $(4.97 \mathrm{mg} / \mathrm{g}$ ) reported by [7]. This content decreases during post-harvest softening. Reduction in total oxalate content was reported by [15] during the storagen of Solanum anguivi berries. Indeed, during ripening the total oxalates content is reduced due to the increase in water content in fruits and vegetables [42].

A phytate intake of 4.00 to $9.00 \mathrm{mg} / 100 \mathrm{~g}$ reduces iron absorption in humans [43]. Phytate content of safou studied from softening stage S0 is $1.46 \pm 0.03 \mathrm{mg} / 100 \mathrm{~g}$ (edulis), $1.43 \pm 0.01 \mathrm{mg} / 100 \mathrm{~g}$ (parvicarpa). These results are corroborated by those reported by [44] in Nigeria which are $1.59 \mathrm{mg} / 100 \mathrm{~g}$ (edulis) and $1.05 \mathrm{mg} / 100 \mathrm{~g}$ (parvicarpa). The decrease of phytate content during postharvest softening was reported by [15]. This would be caused by phytases activation during biochemical and physiological changes that take place in plant during ripening [45]. 


\section{Conclusion}

This study assessed the impact of post-harvest softening on the nutritional and anti-nutritional parameters of the two varieties of safou (Dacryodes edulis). The study showed that antioxidant activity and anti-nutritional factors in safou varied little until the first softening stage (third day after harvest). Then, these parameters are gradually reduced until the end of the experiment. On the other hand, post-harvest softening significantly reduces the content of anti-nutritional compounds (phytates and oxalates). However, this phenomenon leads to a loss of the nutritional value of safou by promoting the degradation of phenolic compounds and the loss of antioxidant power.

\section{Compliance with ethical standards}

\section{Acknowledgments}

This work was supported by a PhD grant to the first author. The authors are grateful to the company Agneby Safou located in Agboville (South-East, Côte d'Ivoire) and to the physico-chemical laboratory of the Swiss center for scientific research (Abidjan, Côte d'Ivoire) for technical assistances.

\section{Disclosure of conflict of interest}

Authors have declared that no competing interests exist.

\section{References}

[1] Kouamé NMT, Soro K, Mangara A, Diarrassouba N, Koulibaly AV and Boraud NKM. (2015).Etude physicochimique de sept (7) plantes spontanées alimentaires du centre-ouest de la Côte d'Ivoire. Journal of Applied Biosciences, 90(1), 8450-8463.

[2] Kadji BRL, Kone FMT, Sika AE and Dabonné S. (2016). Physico-chemical properties of Safou (Dacryodes edulis) fruits grown in Côte d'Ivoire. Journal of Applied Biosciences, 105, 10103-10110.

[3] Ano AAR, Koffi NE, Adima AA, N'da PK and Anin LA. (2018). Composition biochimique et phytochimique des tourteaux des fruits du safoutier (Dacryodes edulis) de Côte d'Ivoire. International. Journal of Biological and Chemical Sciences, 12(6), 2535-2546.

[4] Kadji. (2018). Etude des caractéristiques physicochimiques et du potentiel nutritionnel du safou [Dacryodes edulis (G. Don) H. J. Lam (Burseraceae)] cultivé en côte d'ivoire. Thèse de doctorat, Université Nangui Abrogoua, Côte d'ivoire, 164.

[5] Noumi GB, Djounja T, Ngameni E and Kapseu C. (2014). Influence of the storage time on the fats and oil composition of safou (Dacryodes edulis) dried pulp. International Food Research Journal, 21(5), 1837-1841.

[6] Kengué J. (2002). Fruits for the future 3- Safou- Dacryodes edulis. Research for Development in Department for International Development, 147.

[7] Duru M, Amadi C, Ugbogu A, Eze A and Amadi B. (2012). Phytochemical, vitamin and proximate composition of Dacryodes edulis fruit at different stages of maturation. Asian Journal of Plant Science and Research, 2(4), 437441.

[8] Sika EA, Kadji LRB, Dje MK, Kone MTF, Dabonne S and Koffi-Nevry RA. (2019). Qualité nutritionnelle, microbiologique et organoleptique de farines composées à base de maïs (Zea mays) et de safou (Dacryodes edulis) produites en Côte d'Ivoire. Int. J. Biol. Chem. Sci, 13(1), 325-337.

[9] Crepin EM, Sylvain G and Renard CMGC. (2004). Flavonols and Anthocyanins of Bush Butter, Dacryodes edulis (G. Don) H.J. Lam, Fruit. Changes in Their Composition during Ripening. Journal of Agricultural and Food Chemistry, 51(25), 7475-80.

[10] Oboh G, Ademosun AO, Akinleye M, Omojokun OS, Boligon AA and Athayde ML. (2015). Starch composition, glycemic indices, phenolic constituents, and antioxidative and antidiabetic properties of some common tropical fruits. Journal of Ethnic Food, 2, 64-73.

[11] Ononamadu CJ, Alhassan AJ, Aminu I, Abdullahi AI, Godwin OI, Owolarafe TA and Sule MS. (2019). MethanolExtract/Fractions of Dacryodes edulis Leaves Ameliorate Hyperglycemia and Associated Oxidative Stress in Streptozotocin-Induced Diabetic Wistar Rats. Journal of Evidence-Based Integrative Medicine, 24, 1-12. 
[12] Moise MM, Benjamin LM and Etienne M. (2012). Intake of Gnetum africanum and Dacryodes edulis, imbalance of oxidant/antioxidant status and prevalence of diabetic retinopathy in Central Africans. PLoS One, 7(12), 49411.

[13] Ajibesin KK, Essien EE and Adesanya SA. (2011). Antibacterial constituents of the leaves of Dacryodes edulis, African Journal of Pharmacy and Pharmacology, 5(15), 1782-1786.

[14] Dossou BR, Ella Missang C, Karou S and Ameyapoh Y. (2018). Relationship between texture and cell-wall components of safou (Dacryodes edulis (G. Don) H.J. Lam) fruits at different storage conditions. Journal of Applied Biosciences, 125, 12566-12580.

[15] Dan CG. (2014). Evolution des paramètres biochimiques et physico fonctionnels des baies de Solanum anguivi Lam récoltées en Côte d'Ivoire au cours du mûrissement. Thèse de doctorat, Université Nangui Abrogoua, Côte d'Ivoire, 170.

[16] Yao KJ-B, Atchibri O-AL, Koffi NE, N'da KP and Adima AA. (2016). "Optimisation of total flavonoids and total antioxidants extraction from Dacryodes edulis leaves", International Journal of Current Research, 8(11), 4213042135.

[17] Ozdemir F and Topuz A. (2004). Changes in dry matter, oil content and fatty acids composition of avocado during harvesting time and post-harvesting ripening period. Food Chemistry, 86, 79-83.

[18] Talbi H, Boumaza A, El-mostafa K, Talbi J and Hilali A. (2015). Evaluation de l'activité antioxydante et la composition physico-chimique des extraits méthanolique et aqueux de la Nigella sativa L. Journal of Materials and Environmental Science, 6(4), 1111-1117.

[19] Singleton VL, Orthofer R and Lamuela-Raventos RM. (1999). Analysis of total phenols and other oxydant substrates and antioxydants by means of Folin-ciocalteu reagent. Methods in Enzymology, 299, 152-178.

[20] Bainbridge Z, Tomlins K and Westby A. (1996). Analysis of condensed tannins using acidified vanillin. Journal of Food Science, 29, 77-79.

[21] Meda A, Lamien CE, Romito M, Millogo J and Nacoulma OG. (2005). Determination of total phenolic, flavonoid and proline contents in Burkina Faso honeys as well as their radical scavenging activity. Food Chemistry, 91,571-577.

[22] Oyaizu M. (1986). Studies on products of browning reaction- Antioxidative activities of products of browning reaction prepared from glucosamine. Japanese Journal of Nutrition, 44, 307-315.

[23] Sanchez-Moreno C, Larrauri JA and Saura-calixto F. (1998). A procedure to measure the antiradical efficiency of polyphenols. Journal Science Technology International, 8,121-137.

[24] Latta M and Eskin MJ. (1980). A Simple and rapid colorimetric method for Phytat determination. Journal of Agricultural and Food Chemistry, 28, 1313-1315.

[25] Day RA and Underwood AL. (1986). Quantitative analysis. 5th ed. Prentice Hall, 701.

[26] Huang Y, Renfu Lu, Yifei Xu and Kunjie C . (2018). Prediction of tomato firmness using spatially-resolved spectroscopy, in Postharvest Biology and Technology. Elsevier, 140, 18-26.

[27] Silou T, Massamba D, Goma MJ, Maloumbi G and Biyoko S. (2007). Postharvest losses by natural softening of safou pulp (Dacryodes edulis) in Congo-Brazzaville. Journal of Food Ingineering, 79, 392-400.

[28] Abu-Goukh AA and Bashir A. (2003). Changes in pectic enzymes and cellulase activity during guava fruit ripening. Food Chemistry, 83, 213-218.

[29] Mamiro P, Fweja L, Chove B, Kinabo J, George V and Mtebe K. (2007). Physical and Chemical Mango (Mangifera Indica L.) Fruits varieties of Eastern Tanzania. Tanzania Journal of Biotechnology, 6(21), 2477-2483.

[30] Dossou BR, Ella Missang C, Baron A, Renard CMGC and Silou T. (2012). Factors affecting postharvest preservation of safou (Dacryodes edulis (G. Don) H.J. Lam) fruits. Forests, Trees and Livelihoods, 21(1), 44-55.

[31] Wei L, Yanxiang G, Jian Z and Qi W. (2007). Phenolic, Flavonoid, and Lutein Ester Content and Antioxidant Activity of 11 Cultivars of Chinese Marigold. Journal of Agriculture and Food Chemistry, 55, 8478-8484.

[32] Cissé I. (2012). Caractérisation des propriétés biochimiques et nutritionnelles de la pulpe de baobab des espèces endémiques de Madagascar et d'Afrique continentale en vue de leur valorisation. Thèse de Doctorat Université de Montpellier, France 167. 
[33] Shwartz E, Glazer I, Irit B-Y, Matityahu I, Igal B-I, Holland D and Amir R. (2009). Changes in chemical constituents during the maturation and ripening of two commercially important pomegranate accessions. Food Chemistry, 115, 965-973.

[34] Hodek P, Trefil P et Stiborova M. (2002). Flavonoids-potent and versatile biologically active compounds interacting with cytochromes. Chemico-Biological Interactions, 139, 1-21.

[35] Fawole OA and Opara UL. (2013). Developmental Changes in Maturity Indices of Pomegranate Fruit: A Descriptive Review. Scientia Horticulturae , 159, 152-161.

[36] Morry. (2007). Extraction de l'huile de safou assistée par les enzymes et caractéristiques chimiques de l'huile obtenue. Thèse de doctorat, Université des Sciences et Techniques de Masuku (USTM), Franceville Gabon 112.

[37] Okudu HO, Okudu PC and Mene LP. (2017). Nutrients, phytochemicals and antioxidant properties of two varieties of tropical almond (Terminalia catappa) pulp. International Journal of Food And Nutrition Research, 1(6), 1-6.

[38] Gil MI, Tomas-Barberan FA, Hess-Pierce B, Holcroft DM and Kader AA. (2000). Antioxidant Activity of Pomegranate Juice and its Relationship with Phenolic Composition and Processing. Journal of Agricultural and Food Chemistry, 48, 4581-4589.

[39] Nour V, Trandafir I and Ionica ME. (2014). Evolution of antioxidant activity and bioactive compounds in tomato (Lycopersicon esculentum Mill.) fruits during growth and ripening. Journal of Applied Botany and Food Quality, 87, 97-103.

[40] Fischer UA, Carle R and Kammerer DR. (2011). Identification and quantification of phenolic compounds from pomegranate (Punica granatum L.) peel, mesocarp, aril and differently produced juices by HPLC-DAD-ESI/MSn. Food Chemistry, 127, 807-821.

[41] Akwaowo EU, Ndon BA and Etuk EU. (2000). Minerals and antinutrients in fluted pumpkin (Telfairia ccidentalis Hook f.), Food Chemistry, 70(2), 235-240.

[42] Ghavidel R and Prakash J. (2007). The impact of germination and dehulling on nutrients, antinutrients, in vitro iron and calcium bioavaibility and in vitro starch and protein digestibility of some legume seeds. LWT-Food Science and Technology, 40, 1292-1299.

[43] Hurel D, Lefrant J-Y, Cano NJ, Ichai C, Preiser J-C and Tamion F. (2014). Nutrition artificielle en réanimation Guidelines for Nutrition Support in Critically Ill Patient. Réanimation, 23, 332-350.

[44] Ibanga 0 and Okon D (2009). Minerals and anti-nutrients in two varieties of African pear (Dacryodes edulis). Journal of Food Technology, 7(4), 106-110.

[45] Chavan JK and Kadam SS. (1989). Nutritional improvement of cereals by sprouting. Food Science and Nutrition, 28,401-37.

\section{How to cite this article}

Djédjé BPG, Ekissi ESG, Kadji BRL, Koné FMT and Dabonné S. (2020). Assessment effects of post-harvest softening on the quality of safou (Dacryodes edulis) produced in Agboville (South-East, Côte d'Ivoire). GSC Biological and Pharmaceutical Sciences, 11(2), 80-90. 